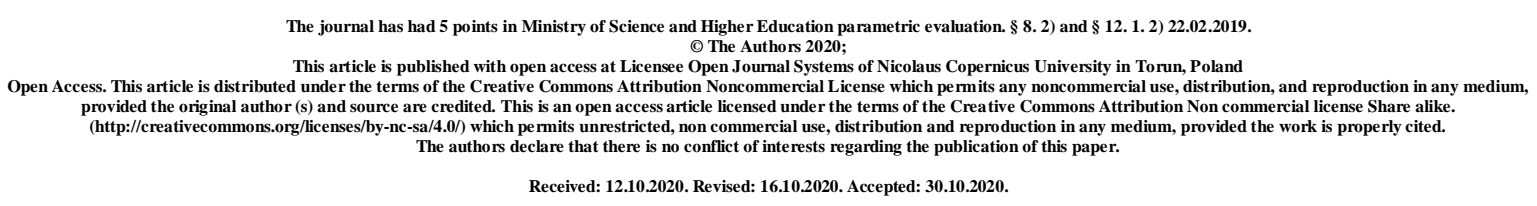

\title{
DYNAMICS OF C-REACTIVE PROTEIN IN CONDITIONS OF SUBSTANCE P BLOCK
}

\author{
O. M. Shevchenko, V. O. Sych
}

\section{Kharkiv National Medical University, Ukraine}

Shevchenko Oleksander Mykolayovych, doctor of medical sciences, professor, Kharkiv National Medical University, professor of the Department of Pathological Physiology honorary named after professor D. O. Alpern, +380978299581, shevchenkoalexandr9@gmail.com, ORCID: 00000001-6008-0362

Corresponding Author: Sych Volodymyr Oleksandrovych, Kharkiv National Medical University, MD, PhD student of the Department of Pathological Physiology honorary named after professor D. O. Alpern, +380675405585, vladimir_sych92@ukr.net, ORCID: 0000-0003-4006-4351

\section{Abstract}

With the aim to determine the features of the concentration of C-reactive protein in the blood in carrageenan secondary chronic inflammation on the background of blockade of substance $\mathrm{P}$ an experimental prospective controlled randomized study was performed on 132 WAG rats in series of 6 rats each in the natural course and using a pharmacological aprepitant praparation - inhibitor of NK-1R in the control and simulated inflammation series for 6 hours, as well as 1,2, 3, 5, 7, 10,14,21, 28 days. the peculiarities of the concentration of C-reactive protein in the blood in carrageenan secondary chronic inflammation on the background of blockade of substance P have been developed.

Key words: C-reactive protein; secondary chronic inflammation; substance $\mathbf{P}$. 


\section{Background}

In inflammation an integral role is played by substance P [1-5]. It is involved in an initiation of T-helpers type 2 migration, associated with intensity of inflammation [6]. The technological level of the laboratory procedures concerning substance $\mathrm{P}$ detection continuously undergo different improvements allowing more and more advanced studies [710]. A relation of C-reactive protein (as a "gold standard" of inflammation marker) to interleukins is known from multiple studies [11-14].

It is known that interleukins and much wider spectrum of intercellular mediators of inflammation, cytokins, are very formally subdivided into two domains - "proinflammatory" (most of them) and "anti-inflammatory" (i. e., interleukins 4 and 10) [15-17]. The latter do not actually "truly" counteract inflammation, but mostly depress cellular reactions (and therefore an inflammation) and "redirect" it to the immune reactions of immediate type (mostly humoral, with immunoglobulins) instead [18].

Despite a huge experience of C-reactive protein (CRP) studies for many years, there is a lack of evidence of a dynamics of CRP blood concentration in conditions of substance P block.

Aim: to determine the features of the concentration of C-reactive protein in the blood in carrageenan secondary chronic inflammation against the background of blockade of substance $P$.

\section{Material and methods}

An experimental prospective controlled randomized study was performed on 132 WAG rats in series of 6 rats each in the natural course and using a pharmacological aprepitant praparation - inhibitor of NK-1R in the control and simulated inflammation series for 6 hours, as well as $1,2,3,5,7,10,14,21,28$ days.

The content of CRP in the natural course of inflammation was estimated with standard biochemical method.

To exclude the influence of natural circadian rhythms on the indicators, the experiment was performed in the autumn-winter period in a standardized way in the morning.

A carrageenan model of inflammation was selected, using $10 \mathrm{mg}$ of $\alpha$-carrageenan (Sigma, USA) in $1 \mathrm{ml}$ of saline [19], which was injected intramuscularly into the rat thigh under thiopental anesthesia.

To inhibit the synthesis and effects of substance P NK-1R inhibitor aprepitant was used, which was administered intraperitoneally at a dose of $10 \mathrm{mg}$ dissolved in $1 \mathrm{ml}$ of isotonic sodium chloride solution, daily throughout the experiment [20]. 
Logical and statistical methods of analysis are applied taking into account the nature of the distribution.

All manipulations on animals were performed in accordance with national and international requirements. The study was approved by the Ethics and Bioethics Commission of Kharkiv National Medical University.

\section{Results and discussion}

The content of CRP in the natural course of inflammation and substance P blockade was estimated (Table 1).

Table 1

Dynamics of concentration of $\mathrm{C}$-reactive protein in the blood in a natural course of inflammation and substance $\mathbf{P}$ blockade, international units/l

\begin{tabular}{|l|c|c|}
\hline \multicolumn{1}{|c|}{$\begin{array}{c}\text { Series } \\
\text { of animals }(\mathrm{n}=6)\end{array}$} & $\begin{array}{c}\text { Substance } \mathrm{P} \\
\text { blockade }\end{array}$ & $\begin{array}{c}\text { Natural } \\
\text { course }\end{array}$ \\
\hline Intact control & $1.93[1.85 ; 2.05]$ & $2.00[1.89 ; 2.07]$ \\
\hline 6 hours & $1.69[1.62 ; 1.77]$ & $2.21[2.17 ; 2.29]$ \\
\hline 1 day & $1.17[1.11 ; 1.25]$ & $3.34[3.29 ; 3.40]$ \\
\hline 2 days & $1.79[1.68 ; 1.84]$ & $3.51[3.47 ; 3.63]$ \\
\hline 3 days & $1.97[1.88 ; 2.00]$ & $3.36[3.28 ; 3.45]$ \\
\hline 5 days & $1.82[1.79 ; 1.82]$ & $2.44[2.37 ; 2.51]$ \\
\hline 7 days & $1.55[1.49 ; 1.60]$ & $2.28[2.19 ; 2.37]$ \\
\hline 10 days & $1.62[1.35 ; 1.97]$ & $1.45[1.42 ; 2.00]$ \\
\hline 14 days & $1.69[1.65 ; 1.75]$ & $1.92[1.88 ; 1.98]$ \\
\hline 21 days & $1.83[1.77 ; 1.92]$ & $1.94[1.65 ; 2.00]$ \\
\hline 28 days & $1.77[1.72 ; 1.85]$ & $1.81[1.78 ; 1.85]$ \\
\hline
\end{tabular}

In the natural course of inflammation, the general trend is a burst-like increase in the concentration of CRP for 1-3 days and a gradual further decrease (Figure. 1).

The curve of the dynamics of the concentration of CRP in the blood was different in case of blockade of substance P comparing with the natural course of inflammation.

Comparing with control, in the natural course of inflammation, trends were identified for concentrations of C-reactive protein - in 6 hours $(\mathrm{p}=0.08)$, in 1 day $(\mathrm{p}=0.08)$, in 2 days $(\mathrm{p}=0.08)$, in 3 days $(\mathrm{p}=0.08)$, in 5 days $(\mathrm{p}=0.05)$, in 7 days $(\mathrm{p}=0.08)$, in 14 days $(\mathrm{p}=0.05)$.

Comparing with the previous duration of modeling of inflammation in the natural course of inflammation, no statistically significant differences were found.

Trends are defined comparing the previous series of duration of inflammation in relation to concentration of C-reactive protein - between 6 hours and 1 day ( $\mathrm{p}=0.08)$, between 1 and 2 days $(\mathrm{p}=0.08)$, between 2 and 3 days $(\mathrm{p}=0.08)$, between 3 and 5 days $(\mathrm{p}=0.05)$, between 7 and 10 days $(\mathrm{p}=0.08)$. 


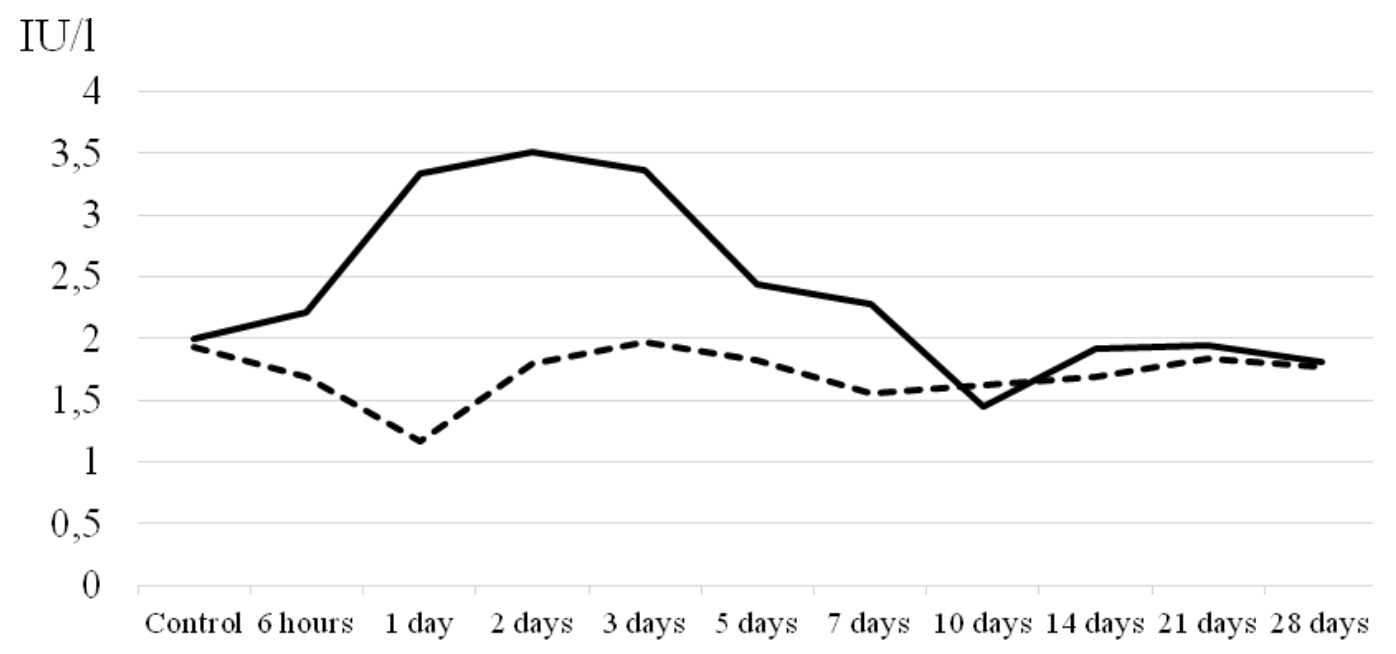

\section{- Natural course ----S Substance P block}

Fig. 1. Dynamics of the concentration of C-reactive protein in the blood during the natural course of inflammation and in case of substance $\mathrm{P}$ blockade

The blood concentrations of CRP in case of blockade of substance P was studied.

Comparing with the control of in case of blockade of substance $\mathrm{P}$, trends in differences are identified for concentration of C-reactive protein - in 6 hours $(p=0.08)$, in 1 day $(p=0.08)$, in 2 days $(\mathrm{p}=0.08)$, in 5 days $(\mathrm{p}=0.08)$, in 7 days $(\mathrm{p}=0.08)$, in 14 days $(\mathrm{p}=0.05)$.

Comparing with the previous duration of inflammation modeling in the natural course of inflammation, trends comparing with the previous series of duration of inflammation are defined in relation to concentration of C-reactive protein - between 6 hours and 1 day $(\mathrm{p}=0.08)$, between 1 and 2 days $(\mathrm{p}=0.08)$, between 2 and 3 days $(\mathrm{p}=0.08)$, between 3 and 5 days $(\mathrm{p}=0.08)$, between 5 and 7 days $(\mathrm{p}=0.08)$, between 14 and 21 days $(\mathrm{p}=0.08)$.

The blood concentration of CRP in series with blocking of substance P in comparison with the natural course of inflammation was analyzed. The tendency to lower values of CRP in 6 hours is established $(\mathrm{p}=0.08)$, in 1 day $(\mathrm{p}=0.08)$, in 2 days $(\mathrm{p}=0.08)$, in 3 days $(\mathrm{p}=0.08)$, in 5 days $(\mathrm{p}=0.05)$, in 7 days $(\mathrm{p}=0.08)$, in 14 days $(\mathrm{p}=0.05)$.

Thus, the peculiarities of the concentration of C-reactive protein in the blood in carrageenan secondary chronic inflammation on the background of blockade of substance $\mathrm{P}$ have been revealed.

The revealed trends in the dynamics of CRP blood concentration separately correlate with the scattered in multiple studies of other authors [3, 5, 11-14, 21-23]. Thus, it is 
reasonable that substance $\mathrm{P}$ depression is associated with less expressive dynamics of CRP blood concentration because as soon as substance $\mathrm{P}$ has shown the involvement in the process of an inflammation upregulation [5, 21].

\section{Conclusions.}

1. The blood concentration of CRP in case of blockade of substance P vary, and statistical tendencies are found.

2. Trends in differences comparing with control are identified for concentration of Creactive protein - in 6 hours $(\mathrm{p}=0.08)$, in 1 day $(\mathrm{p}=0.08)$, in 2 days $(\mathrm{p}=0.08)$, in 5 days $(\mathrm{p}=0.08)$, in 7 days $(\mathrm{p}=0.08)$, in 14 days $(\mathrm{p}=0.05)$. This finding requires more thorough research with higher statistical power.

Prospects of further research concern the development of a criterional complex of blood system reactions system forecasting in the conditions of inflammation and effects of substance P blocking.

\section{References}

1. Kinobe, R. T., \& Miyake, Y. (2020). Evaluating the anti-inflammatory and analgesic properties of maropitant: A systematic review and meta-analysis. Veterinary Journal (London, $\quad$ England: 1997$), \quad 259-260, \quad 105471$. https://doi.org/10.1016/j.tvj1.2020.105471

2. Graefe, S., \& Mohiuddin, S. S. (2020). Biochemistry, Substance P. In StatPearls. StatPearls Publishing. http://www.ncbi.nlm.nih.gov/books/NBK554583/

3. Rychlik, A., Gonkowski, S., Makowska, K., Kaczmar, E., \& Calka, J. (2020). Changes in the expression of substance $\mathrm{P}$ in nerve fibres of the colonic mucosa in dogs suffering from inflammatory bowel disease. Acta Veterinaria Hungarica, 68(2), 154-159. https://doi.org/10.1556/004.2020.00028

4. Hodo, T. W., de Aquino, M. T. P., Shimamoto, A., \& Shanker, A. (2020). Critical Neurotransmitters in the Neuroimmune Network. Frontiers in Immunology, 11, 1869. https://doi.org/10.3389/fimmu.2020.01869

5. Barbosa-Cobos, R. E., Lugo-Zamudio, G., Flores-Estrada, J., Becerril-Mendoza, L. T., Rodríguez-Henríquez, P., Torres-González, R., Moreno-Eutimio, M. A., Ramirez-Bello, J., \& Moreno, J. (2018). Serum substance P: An indicator of disease activity and subclinical inflammation in rheumatoid arthritis. Clinical Rheumatology, 37(4), 901-908. https://doi.org/10.1007/s10067-017-3929-6 
6. Cheadle, C. E., Glencross, D. A., \& Hawrylowicz, C. M. (2020). Allergens TRP a swITCH to Initiate Type 2 Immunity. Immunity, 53(5), 900-902. https://doi.org/10.1016/j.immuni.2020.10.019

7. Schreiber, U., Engl, C., Bayer, M., \& König, S. (2020). Labeled substance P as a neuropeptide reporter substance for enzyme activity. Journal of Pharmaceutical and Biomedical Analysis, 178, 112953. https://doi.org/10.1016/j.jpba.2019.112953

8. Schreiber, U., Engl, C., Bayer, M., \& König, S. (2020). Neuropeptide reporter assay for serum, capillary blood and blood cards. MethodsX, 7, 100985. https://doi.org/10.1016/j.mex.2020.100985

9. Feickert, M., \& Burckhardt, B. B. (2020). Mass spectrometric studies on the peptide integrity of substance P and related human tachykinins in human biofluids. Peptides, 170458. https://doi.org/10.1016/j.peptides.2020.170458

10. Feickert, M., \& Burckhardt, B. B. (2020). Validated mass spectrometric assay for the quantification of substance $\mathrm{P}$ and human hemokinin-1 in plasma samples: A design of experiments concept for comprehensive method development. Journal of Pharmaceutical and Biomedical Analysis, 191, 113542. https://doi.org/10.1016/j.jpba.2020.113542

11. Slaats, J., Ten Oever, J., van de Veerdonk, F. L., \& Netea, M. G. (2016). IL-1ß/IL6/CRP and IL-18/ferritin: Distinct Inflammatory Programs in Infections. PLoS Pathogens, 12(12), e1005973. https://doi.org/10.1371/journal.ppat.1005973

12. Ji, A.-L., Liu, Z.-H., Chen, W.-W., \& Huang, W.-J. (2016). The clinical significance of level changes of hs-CRP, IL-10 and TNF for patients with MS during active and relieving period. European Review for Medical and Pharmacological Sciences, 20(20), 4274-4276.

13. Del Giudice, M., \& Gangestad, S. W. (2018). Rethinking IL-6 and CRP: Why they are more than inflammatory biomarkers, and why it matters. Brain, Behavior, and Immunity, 70, 61-75. https://doi.org/10.1016/j.bbi.2018.02.013

14. Felger, J. C., Haroon, E., Patel, T. A., Goldsmith, D. R., Wommack, E. C., Woolwine, B. J., Le, N.-A., Feinberg, R., Tansey, M. G., \& Miller, A. H. (2020). What does plasma CRP tell us about peripheral and central inflammation in depression? Molecular Psychiatry, 25(6), 1301-1311. https://doi.org/10.1038/s41380-018-0096-3

15. Uciechowski, P., \& Dempke, W. C. M. (2020). Interleukin-6: A Masterplayer in the Cytokine Network. Oncology, 98(3), 131-137. https://doi.org/10.1159/000505099 
16. Nasirzade, J., Kargarpour, Z., Hasannia, S., Strauss, F. J., \& Gruber, R. (2020). Platelet-rich fibrin elicits an anti-inflammatory response in macrophages in vitro. Journal of Periodontology, 91(2), 244-252. https://doi.org/10.1002/JPER.19-0216

17. Grossi, V., Gulli, F., Infantino, M., Stefanile, A., Napodano, C., Benucci, M., Pocino, K., Li Gobbi, F., Damiani, A., Di Pino, A., Manfredi, M., Marino, M., Basile, V., Rapaccini, G. L., \& Basile, U. (2020). The Laboratory Role in anti-TNF Biological Therapy $\begin{array}{llll}\text { Era. Immunological } & \text { Investigations, }\end{array}$ https://doi.org/10.1080/08820139.2019.1637434

18. Fang, D., \& Zhu, J. (2020). Molecular switches for regulating the differentiation of inflammatory and IL-10-producing anti-inflammatory T-helper cells. Cellular and Molecular Life Sciences: CMLS, 77(2), 289-303. https://doi.org/10.1007/s00018-019-03277-0

19. Klymenko, M., Tatarko, S., Shevchenko, O., \& Hubina-Vakulyk, G. (2007). Substantiation of the model of chronic (secondary chronic) inflammation. Experimental and Clinical Medicine, 2, 24-28.

20. Lim, R., Morrill, J. M., Prushik, S. G., Reed, K. L., Gower, A. C., Leeman, S. E., Stucchi, A. F., \& Becker, J. M. (2008). An FDA Approved Neurokinin-1 Receptor Antagonist is Effective in Reducing Intraabdominal Adhesions when Administered Intraperitoneally, But Not Orally. Journal of Gastrointestinal Surgery, 12(10), 1754-1761. https://doi.org/10.1007/s11605-008-0634-4

21. Patel, M., Valaiyaduppu Subas, S., Ghani, M. R., Busa, V., Dardeir, A., Marudhai, S., \& Cancarevic, I. (2020). Role of Substance P in the Pathophysiology of Inflammatory Bowel Disease and Its Correlation With the Degree of Inflammation. Cureus, 12(10), e11027. https://doi.org/10.7759/cureus.11027

22. Fehér, E., \& Altdorfer, K. (2020). Neuroimmunomodulation in the mucosa of the alimentary tract. Orvosi Hetilap, 161(35), 1436-1440. https://doi.org/10.1556/650.2020.31795

23. Sánchez, P., Sánchez, M. L., Mangas, A., Aguilar, L. Á., \& Coveñas, R. (2020). A close neuroanatomical relationship between the enkephalinergic (methionine-enkephalin) and tachykininergic (substance P) systems in the alpaca diencephalon. Folia Histochemica Et Cytobiologica, 58(2), 135-146. https://doi.org/10.5603/FHC.a2020.0007 